\title{
CORPORATE PROXY CONTESTS: SOLICITATION AND VALIDITY OF BROKERS' PROXIES*
}

\author{
EDThard Ross Arawow and Herbert A. EINHorN†
}

$\longrightarrow$ HE marked increase, in recent years, in the number and importance of corporate proxy contests is apparent even to the most casual reader of the daily press. The New York Central Railroad, the New York, New Haven and Hartford Railroad, Montgomery Ward, Fairbanks Morse, and many other well known corporations have been the subject of highly publicized contests. Many other corporations, not so well known, but nevertheless affecting thousands of stockholders and many millions of dollars of assets, have also been involved in proxy contests. ${ }^{1}$

The development and increased importance of such contests may be traced to the growth in the size of corporate enterprises and the accompanying dispersion of corporate stock throughout the expanding investing public. It is now unusual for a management group to hold a majority of voting stock of a substantial corporation, and thus have "absolute" control. Control of a large corporation usually is based on "effective" or "working" control; and many managements do not even have such control.

Thus, in a contest for control, it is usually necessary for each group, management and insurgents, to enlist the support of many uncommitted stockholders by soliciting their votes or proxies. ${ }^{2}$ In preparing for such solicitation, generally a substantial amount of stock is found registered in the name of stock brokers or banks, commonly referred to as "street name." The real or beneficial owners of such stock are usually customers of the broker or bank who, for a variety of reasons, prefer to have the stock registered in street name rather than in their own names. Brokers and bankers treat the identity of their customers as confidential.

It is now well recognized that in many proxy contests, the stock held in

* This article is based on chapters of a book by the authors to be published later this year by the Columbia University Press, under the title Corporate Meetings, Proxy Contests and Legal Remedies. Irving Novick and Lloyd I. Singer assisted in its preparation.

t Members of the firm of Aranow, Brodsky, Bohlinger, Einhorn \& Dann, New York City.

${ }^{1}$ There were twenty-one contests in 1954 and seventeen in 1955, involving corporations whose securities were listed on national exchanges and thereby subject to the Proxy Rules of the Securities and Exchange Commission. Orrick, 183 Commercial and Financial Chron. 474 (Jan. 26, 1956). There were other contests which were not subject to the SEC Proxy Rules.

${ }^{2}$ If the corporation's voting stock is listed on a national securities exchange, as is the case of most large publicly held corporations, the solicitation of proxies is subject to the Proxy Rules of the SEC. 
street name is of crucial importance and often represents the balance of power. In a study made in 1954 of the stock ownership of twenty-seven companies, it was found that on the average the total broker-held stock represented 23 per cent of the outstanding stock and 24.9 per cent of the stockholders. There are many companies in which the percentage of broker-held stocks runs as high as 40 per cent. ${ }^{3}$ Therefore, both sides in a proxy contest must devote considerable time, energy and money to the solicitation of proxies from the broker-held stock. Certain professional proxy soliciting organizations have representatives who specialize in dealing with the brokers and obtaining their proxies.

The fact that stock held in street name is not owned by the broker but is owned by the broker's customer has presented special problems in the solicitation of proxies. Moreover, special problems as to the validity of proxies executed by brokers have arisen by reason of practical difficulties often encountered by the brokers.

\section{SOLICITATION OF BROKERS' PROXIES}

The regulation of the solicitation and execution of broker proxies is of two types: (1) federal regulation under the Securities Exchange Act of 1934, ${ }^{4}$ and (2) self-regulation under the particular stock exchange rules. Though there are state statutes relating to stockholders' meetings and the determination of the validity of brokers' proxies, ${ }^{5}$ the actual solicitation of proxies and the power of brokers to execute proxies in the absence of instruction from the beneficial owners are all free from state regulation.

\section{Federal Regulation-SEC Proxy Rules}

In discussing the applicability of the SEC Proxy Rules to the solicitation of broker-held stock, it is necessary to understand clearly the two-step type

s The importance of securing the vote of the broker-held stock is illustrated by the following tabular presentation of the voting in the 1954 contest for control of the New York Central Railroad.

\begin{tabular}{|c|c|c|c|c|}
\hline \multirow[t]{2}{*}{ rork ceilial Rainual. } & \multicolumn{2}{|c|}{ SHARES } & \multicolumn{2}{|c|}{ No. of Proxies } \\
\hline & Young & White & Young & White \\
\hline Nominees for Director. . & $1,091,000$ & \multirow{3}{*}{$\left.\begin{array}{l}106,000 \\
652,000 \\
170,000\end{array}\right\}$} & \multirow{3}{*}{$\begin{array}{r}15 \\
393\end{array}$} & \multirow{3}{*}{$\begin{array}{r}15 \\
510\end{array}$} \\
\hline Broker-held & $1,070,000$ & & & \\
\hline $\begin{array}{l}\text { Bank Nominees } \ldots \ldots \ldots \ldots \ldots \\
\text { Other Shareholders: }\end{array}$ & 60,000 & & & \\
\hline 1-99 Shares ......... & 170,000 & 319,000 & 7,500 & 17,800 \\
\hline 100-499 Shares ... & 501,000 & 626,000 & 4,300 & 4,400 \\
\hline \multirow[t]{2}{*}{500 and over Shares..$\ldots \ldots$} & 423,000 & 467,000 & 314 & 308 \\
\hline & 5,000 & $2,340,000$ & 12,522 & 23,033 \\
\hline
\end{tabular}

Source: Georgeson and Co., Trends in Management-Stockholder Relations (1954).

4 48 Stat. 881 (1934), 15 U.S.C.A. \$ 78 (1951).

${ }^{5}$ E.g., Illinois Business Corporation Act, III. Rev. Stat. (1955) c. 32. 
of solicitation involved. The broker is the record holder of the stock, and as such, the only person entitled to vote at the meeting or to execute a proxy. ${ }^{6}$ Therefore, a soliciting group must solicit proxies from the broker. The broker cannot give proxies, except in certain uncontested matters, unless he has received voting instuctions from his customers who are the beneficial owners. ${ }^{7}$ This explains the two-step process: first, the soliciting group solicits proxies from the broker; second, the broker seeks the instructions from his customers.

The first step in the process, the solicitation of the broker, is subject to all of the SEC Proxy Rules. ${ }^{8}$ All the material used in this solicitation must be filed with the Commission in preliminary and definitive form pursuant to Rules X-14A-6 and X-14A-11. All statements made are subject to the antifraud provisions of Rule X-14A-9.

On the other hand, the solicitation by the broker of his customers is exempt from the Proxy Rules if the solicitation meets the conditions of Rule $\mathrm{X}-14 \mathrm{~A}-2$ (b). That rule exempts:

Any solicitation by a person in respect of securities carried in his name or in the name of his nominee (otherwise than as voting trustee) or held in his custody, if such person-

(1) receives no commission or remuneration for such solicitation, directly or indirectly, other than the reimbursement of reasonable expenses,

(2) furnishes promptly to the person solicited a copy of all soliciting material with respect to the same subject matter or meeting received from all persons who shall furnish copies thereof for such purpose and who shall, if requested, defray the reasonable expenses to be incurred in forwarding such material, and

(3) in addition, does no more than impartially instruct the person solicited to forward a proxy to the person, if any, to whom the person solicited desires to give a proxy, or impartially request from the person solicited instructions as to the authority to be conferred by the proxy and state that a proxy will be given if no instructions are received by a certain date. ${ }^{9}$

Section 14(b) of the Securities Exchange Act of $1934^{10}$ made it unlawful for brokers to give proxies for stock of which they were only the record owners in contravention of rules to be prescribed by the Commission. The Commission thus far has not prescribed any such rules. However, the broker's execution of a proxy after receipt of instructions has been governed by the

- General Investment Co. v. American Hide \& Leather Co., 97 N.J. Eq. 214, 127 Atl. 529 (1925); cases cited in note 27 infra.

" Consult New York Stock Exchange Rule as quoted in note 12 infra.

${ }^{8}$ Reg. X-14, under Securities Exchange Act of 1934, 17 Code Fed. Regs. 240.14(a) (Cum. Supp., 1956), as amended 21 Fed. Reg. 577 (1955).

${ }^{2}$ Tbid., at 2 (b).

${ }^{10} 48$ Stat. 881 (1934), 15 U.S.C.A. $\$ 78 \mathrm{n}(\mathrm{b})$ (1951). 
Stock Exchange Rules. More recently, 1955, the Commission announced that it was considering promulgation of a proposed Rule X-14B-1 which is designed to implement Section 14(b) and which, in substance, is very similar to the existing Stock Exchange Rules. ${ }^{11}$

There is nothing either in the Stock Exchange Rules governing the solicitation of voting instructions, or in the SEC Proxy Rules, which prevents a broker from taking sides in the contest by advising his customers on how to execute their proxies. However, should a broker undertake such action, he would no longer come under the exemption of SEC Proxy Rule X-14A-2(b). That exemption from the proxy solicitation rules applies only where the broker does no more than "impartially" request instructions.

In many situations, of course, it is difficult if not impossible for a broker to achieve strict neutrality. It is unlikely that a firm will undertake in writing to advise its customers how to vote. However, it is a common occurrence during the course of a contest for a broker's customers to ask for advice on how to execute the instruction cards they have received. Under such circumstances, it would be unrealistic to expect the broker to refuse to give the requested advice; and while doing so, his preferences or prejudices may readily become apparent.

\section{Stock Exchange Rules on Brokers' Proxy}

The execution by brokers of proxies for stock held in street name is regulated by the rules of the exchange of which the broker is a member. ${ }^{12}$ These

12 Sec. Exch. Act Rel. No. 5166, May 5, 1956 and Sec. Exch. Act Rel. No. 5299, April 17, 1956. The Commission has not indicated whether this proposed rule will be adopted, or if adopted, when it will become effective.

I2 The most important New York Stock Exchange Rules read:

"Rule 870 . No member firm or member corporation shall give a proxy to vote stock registered in its name, except as required or permitted under the provisions of Rule 872, unless such firm or corporation is the beneficial owner of such stock.

Rule 871. Whenever a person soliciting proxies shall furnish a member firm or member corporation: (1) copies of all soliciting material which such person is sending to registered holders, and (2) satisfactory assurance that he will reimburse such member firm or member corporation for all out-of-pocket expenses, including reasonable clerical expenses, if any, incurred by such firm or corporation, in obtaining instructions from the beneficial owners of stock, such firm or corporation shall transmit to each beneficial owner of stock which is in its possession or control the material furnished together with a request for voting instructions and also a statement to the effect that, if such instructions are not received by the tenth day before the meeting, the proxy may be given at discretion by the owner of record of the stock. However, when the proxy soliciting material is transmitted to the beneficial owner of the stock twenty-five days or more before the meeting, the statement accompanying such material shall be to the effect that the proxy may be given fifteen days before the meeting at the discretion of the owner of record of the stock. This rule shall not apply to beneficial owners outside the United States.

Rule 872. A member firm or member corporation shall give a proxy for stock registered in its name, at the direction of the beneficial owner. If the stock is not in the control or 
rules indicate that the broker is a "middleman" in a proxy contest. He receives copies of soliciting material from both sides and sends them to his customers, the beneficial owners of the stock registered in his name. He includes a card by which the beneficial owner can direct him as to how to execute the proxy representing the owner's shares. On the basis of these instructions, the broker executes proxies and sends them to the appropriate soliciting group.

According to Stock Exchange Rule 872,13 a broker may give a proxy at his discretion for shares held in "street name" for a customer who has failed to return the instruction card by a date specified in the statement furnished

possession of the member firm or member corporation, satisfactory proof of the beneficial ownership as of the record date may be required.

A member firm or a member corporation may give a proxy to vote any stock registered in its name if such firm or corporation holds such stock as executor, administrator, guardian, trustee, or in a similar representative or fiduciary capacity with authority to vote.

A member firm or member corporation which has transmitted proxy soliciting material to the beneficial owner of stock in accordance with the provisions of Rule 871, and which has not received instructions from the beneficial owner by the date specified in the statement accompanying such material, may give a proxy to vote such stock, provided the person signing the proxy has no knowledge of any contest as to the action to be taken at the meeting and provided such action does not include authorization for a merger, consolidation or any other matter which may affect substantially the legal rights or privileges of such stock.

A member firm or member corporation which has in its possession or control stock registered in the name of another member firm or member corporation shall (1) forward to the second member firm or member corporation any voting instructions received from the beneficial owner, or (2) if the proxy-soliciting material has been transmitted to the beneficial owner of the stock in accordance with Rule 871 and no instructions have been received by the date specified in the statement accompanying such material, notify the second member firm or member corporation of such fact in order that such firm or corporation may give the proxy as provided in the third paragraph of this Rule.

Rule 873. In all cases in which a proxy is given by a member firm or member corporation the proxy shall state the actual number of shares of stock for which the proxy is given.

Rule 874. A member firm or member corporation, when so requested by the Exchange shall transfer certificates of a listed stock held either for its own account or for the account of others, if registered in the name of a previous holder of record, into its own name, prior to the taking of a record of stockholders, to facilitate the convenient solicitation of proxies.

The Exchange will make such request at the instance of the issuer or of persons owning in the aggregate at least ten per cent of such stock, provided, if the Exchange so requires, the issuer or persons making such request agree to indemnify member firms and member corporations against transfer taxes, and the Exchange may make such a request whenever it deems it advisable.

Rule 875 . Rules 870 through 874 shall apply also to individual members and to any nominees of member firms, member corporations or individual members. They shall apply also to voting in person."

The same rules have been adopted by the American Stock Exchange (Rules 575 through 580 ). The other national exchanges either by practice or by rules generally follow the New York Stock Exchange's Proxy Rules.

${ }^{13}$ Quoted in note 12 supra. 
when the proxy material was transmitted. However, the broker has this power only (1) if he has no knowledge that there will be a contest at the meeting, as to the matter on which he undertakes to vote and (2) if he has no knowledge that a proposal will be voted upon which "may affect substantially the legal rights or privileges of such stock."

Election of Directors. Where there is a proxy contest for the control of a corporation, the application of Rule 872 is clear. If such a contest is in progress and opposing factions are soliciting proxies to elect directors, a broker's proxies must be limited to those shares held by customers who have forwarded specific voting instructions.

A problem can arise, however, where the broker receives the management proxy statement and proxy form for transmittal to his customers at a time when there is no contest and where a contest is undertaken after the broker has acted upon the failure of his clients to return the instruction cards. Such a situation developed in a recent contest in which the authors served as counsel to the management.

Two months before the date of the annual meeting, a dissident stockholder sent out a letter criticizing the president of the company and requesting sympathetic stockholders to sign a return postcard indicating interest in the formation of a protective committee. A month later the management sent out its proxy statement and proxy form, furnishing brokers with materials for transmittal to the beneficial stockholders. The proxy statement made no mention of a contest for the election of directors, as the management could not possibly tell what further action, if any, the dissident individual would take.

The brokers acted upon the then appparent premise that there would be no counter-solicitation. Upon the expiration of the time limit specified in the forwarding letter to their clients, some of the brokers proceeded to execute management proxies for shares held by clients who had not returned instruction cards. However, twelve days before the meeting, the dissident stockholder, acting through a protective committee, came forth with a proxy statement and a full slate of directors. He went to the Stock Exchange and asked that action be taken to invalidate the proxies sent to the management by brokers who had not received instructions. $\mathrm{He}$ argued that such proxies violated Rule 872 since a "contest" was in progress. The ruling body of the Exchange directed all brokers to rescind all proxies sent in and to execute new ones limited to shares held by clients who had furnished voting instructions.

This indicates the problem faced by the brokers. If they have knowledge of a contest, they cannot vote shares without instructions from the beneficial owners. But at the time they are asked to transmit the management solicitation materials, there may be only a threat of a possible contest, such as the 
distribution of a circular strongly criticizing the management. It is at this point, however, that the brokers must inform their clients that their shares will be voted in the absence of instructions. Unless they have knowledge of the fact that there will be a counter-solicitation of proxies to elect a slate of directors different from the slate nominated by the management, they do not really have any knowledge of "a contest." Thus they are justified in giving proxies for the shares for. which no instructions are received. Should an actual counter-solicitation develop subsequently, the broker will be obliged to revoke the proxies already given to the extent that they represent shares for which no instructions were received. At the same time, it would also be advisable for the broker to inform the owners of these shares that they will not be voted unless instructions are received.

In the above situation, the management may find it necessary to make a special effort to solicit proxies from those stockholders who failed to return a proxy in reliance on the statement that their stock would be voted as management desired if they failed to return a proxy by the date specified.

Proposals. The proposals upon which a broker may not vote without instructions from the beneficial owner are of two types:

(1) Proposals which authorize a merger, consolidation or other matter substantially affecting the legal rights or privileges of the stock being solicited. $^{14}$ This restriction is not limited to management's proposals. A stockholder may present proposals through either the medium of his own proxy form, or the management's proxy form pursuant to Rule X-14A-8 of the Proxy Rules. If the stockholder's proposal is of the "affecting right" type, the broker may not vote for or against it without instructions. In these cases, the prohibition relates to the subject matter of the proposal. It makes no difference whether or not they are contested.

(2) Proposals as to which there is a "contest." When an opposition group is soliciting proxies to elect its nominees to the board of directors, it often will present proposals for stockholders' approval. Where the management is opposed to any such proposal, there is a "contest" as to the action to be taken on that proposal. Therefore, a broker may not vote on that proposal without instructions, even if it is not the type of proposal "which may affect substantially the legal rights or privileges" of the stockholders. The same holds true in the case of a management-sponsored proposal which is opposed by the insurgents; or a stockholder's proposal, presented on the management's proxy form pursuant to Rule X-14A-8, to which management indicates its opposition.

Proxies Containing Several Matters. A more difficult situation arises where the proxy solicited refers to more than one matter. A broker may not, with-

14 The New York Stock Exchange-Company Manual (hereinafter cited, Company Manual) lists sixteen situations where, in the opinion of the Exchange's staff, a broker may not give a proxy without instructions from the beneficial owner. Ibid., at A-137-38. 
out instructions, ${ }^{15}$ vote on any matter which is "contested" or of the "affecting rights" type. However, this restriction does not affect the broker's power to give a proxy on uncontested matters of the "non-affecting rights" type to be considered at the same meeting, if no instructions are received during the specified time period. The procedure normally followed by most brokerage houses is to cross out the section of the proxy form which relates to matters upon which they may not vote without instructions and then sign and forward the proxy thus limited.

There appears to be a gap of some importance under the Stock Exchange Rules. The simplest method of presenting this problem is by the use of an example:

A corporation is in the midst of an election contest. The management's proxy statement lists its nominees for election as directors and includes a proposal for the selection of independent auditors (a proposal not of the "affecting rights" type) which is not contested. Although the broker may not vote on the contested election of directors, he may vote, without instructions, on the proposal.

The insurgent group, in order to obtain more time to solicit proxies, plans to stay away from the meeting and thereby force an adjournment because of the lack of a quorum. However, the proxies which the brokers have given, relating only to the proposal and not to the election of directors, apparently may be counted for quorum purposes. Thus, it may be possible for these limited brokers' proxies to be of assistance to one of the sides in a contest. This seems contrary to the basic intent of the Stock Exchange Rules. An amendment of the Rules to cover and clarify such situations may well be desirable.

\section{Methods and Procedures for Soliciting through Brokers}

As already indicated, the solicitation of proxies for broker-held stock involves two distinct steps. The broker, as record owner and the one entitled to vote or give the proxy, must be solicited. The broker, in turn, must obtain instructions from the beneficial owner. The methods and procedures to be followed by a soliciting group are designed to serve these dual purposes.

The Search Letter. A search letter is sent to each broker informing him of the date of the meeting and record date for determination of stockholders entitled to vote. ${ }^{16}$ The broker is told that the sender intends to avail himself of the broker's services in the transmittal of solicitation materials in accord-

${ }^{15}$ Under certain conditions merely signing and returning the instruction card without indicating voting preference as to each proposal are sufficient "instructions" to allow the broker to execute a proxy on all matters to be acted upon. Consult p. 649 infra.

${ }^{16}$ The Company Manual, A-134, suggests that this letter be sent from one to two weeks in advance of the date of the meeting. 
ance with the rules of the exchange of which the broker is a member. It requests information as to how many sets of soliciting material the broker requires; i.e., how many customers hold stock in the corporation involved. The writer agrees to reimburse the broker for his out-of-pocket expenses incurred in obtaining instructions from his customers. ${ }^{17}$

The search letter and return postcard are not deemed to be solicitation material within the scope of the Proxy Rules, providing they do not contain campaign material.

Materials to be Furnished to the Broker. When the proxy material is to be distributed to the stockholders, each broker is sent the number of sets of material indicated on his return postcard. The broker must at the same time be furnished with one transmittal letter and one instruction card for each set of material and stamped envelopes ${ }^{18}$ for his use in mailing all this material to his clients. ${ }^{19}$

Transmittal Letter. The transmittal letter is printed by the soliciting group for the broker's use as a type of covering letter. It explains the source of the proxy material, which matters the broker has discretion to vote upon without receiving instructions and which matters require instructions before the broker may vote. The letter is printed without any signature. Before using the letter, the broker will stamp his own name as signer. Certain brokers will print their own letter, charging the cost back to the soliciting group.

Proxy Rule X-14A-4 (a) requires that the proxy form indicate in bold face type the party soliciting the proxy. Although there is no express similar requirement in reference to a transmittal letter, the Commission will require that the name of the soliciting party appear in bold face type. ${ }^{20}$

Instruction Card. The instruction card (sometimes referred to as the authorization card) is the vital document in the solicitation of broker-held stock in a proxy contest. By use of the instruction card the customer acknowledges receipt of the proxy materials forwarded by the broker, and instructs the broker to sign a proxy for his shares in the form submitted by

\footnotetext{
${ }^{17}$ Rule 871, quoted in note 12 supra, requires this. In February 1952, the New York Stock Exchange approved a standard charge in order to promote uniformity in the charges made by member firms. The standard charge is per set of proxy materials. The Exchange has pointed out that its current charges are subject to revision in light of changed business costs. They are not fixed rates binding on member firms, but only an indication of what the Exchange considers a fair and reasonable charge. Company Manual, A-136. It has been the authors' experience that brokerage firms generally adhere to the standard charges.

${ }^{18}$ The envelope may be stamped or arrangement can be made for the broker to advance postage costs. The broker will stamp his own name and address as the return address on the envelope, and will address the envelope to the customer.

${ }^{10}$ The Company Manual, A-136, suggests delivery of this material at least twenty days prior to the meeting date, to insure early return of proxies to the soliciting group.

${ }^{20}$ Consult Company Manual, A-135-36, for examples of appropriate language in transmittal letters.
} 
the particular soliciting group. The instruction card provides the means for authorizing the broker to execute a proxy on all matters to be considered at the meeting. However, if there are proposals to be voted on at the meeting, the instruction card must provide a means by which the customer can specify a choice between approval or disapproval of each matter to be acted upon. This requirement exists regardless of whether the proposal is one on which the broker may or may not act without specific instructions. The means by which the customer can indicate his wish in reference to proposals should be presented in the same way, and with the same impartiality, as the presentation made in the regular proxy form in conformance with Rule X-14A-4(b).

Experience has shown that in almost every proxy contest a number of record stockholders will sign and return proxies without making use of the means provided to specify a choice on proposals. For this reason, Rule $\mathrm{X}-14 \mathrm{~A}-4$ (b) permits the proxy to confer discretionary authority on the proxy agents in voting on these proposals if the proxy form states how the shares will be voted in each case. This aspect of the solicitation of record holders must be carried over into the secondary solicitation of beneficial holders. This is done by a statement in the instruction card which authorizes the broker, in the absence of specification by the customer, to vote his shares on the proposals in the way recommended by the soliciting group which the customer is supporting by signing that particular instruction card.

The instruction card should provide a space for the customer to affix the date of signing. The reason for this is the same as the reason for the dating of regular proxy forms. Stockholders often change their minds during the course of a proxy contest, so that two or more proxies may be received from the same stockholder. It becomes necessary to determine which of these proxies is the later one. In the case of instruction cards, if more than one card is received from a customer, the broker must look at the dates of execution to determine which is the latest instruction and the one he will follow in executing the regular proxy forms to the soliciting groups.

The transmittal letter and instruction card are solicitation material within the scope of the Proxy Rules. Rule X-14A-6 requires that 3 copies be filed with the Commission in preliminary form at least ten days (unless acceleration is granted) before the date on which this material will be furnished to the brokers.

Solicitation Materials. The solicitation materials furnished to the broker for transmittal to his customers are the same materials that are mailed out to the record stockholders. In the case of a letter preliminary to actual solicitation, the broker need be furnished only with the number of letters he requires and stamped envelopes for mailing them to his customers. No transmittal letter or instruction card is necessary since the customer is not being 
requested to forward instructions on the voting of his shares. The request for instructions occurs at the time the customer is furnished with the proxy statement and regular proxy form. (In the case of the management solicitation for the election of directors, the annual report must also be furnished at this time if it has not already been furnished.) ${ }^{21}$ It is in conjunction with these latter materials that the transmittal letter and instruction card are used.

Follow-up letters are frequently used in a proxy contest. The important aspect of this type of letter, from the viewpoint of solicitation of brokerheld stock, is that the letter to the record stockholder generally will be accompanied by a regular proxy form that the stockholder can use in case he has misplaced the form originally furnished with the proxy statement. In such a case, the broker likewise must again be furnished with an instruction card for enclosure with each set of follow-up material.

When the solicitation material forwarded by the broker to his customers includes a regular proxy form, there is danger that a customer may mistakenly believe that he can vote in the election by signing the regular proxy form and mailing it directly to the soliciting group. Steps should be taken to avoid such confusion. The transmittal letter should state clearly that the customer is to execute the instruction card and not the regular proxy form. In addition, it is most advisable clearly and boldly (preferably in a contrasting color) to stamp all the proxy forms used in this kind of solicitation to indicate that it is only a specimen and not to be executed.

If a customer should sign the regular proxy form and return it to his broker, the broker should treat that form as the equivalent of an instruction card and give a proxy for the customer's shares in the manner indicated by the proxy form. If the customer mails a regular proxy form to the soliciting group, the group should mail the proxy back to him with an explanatory letter. The letter should explain that since the signer of the proxy is not a stockholder of record, he may not give a proxy. He should be requested to execute and return the instruction card to his broker. Such a letter should say no more than that, or its use (without previously filing it with the SEC) would be a violation of Proxy Rule X-14A-6(b).

\section{VALIDITY OF BROKERS' PROXIES}

\section{DETERMTNATION BY INSPECTORS OF ELECTION}

Normally, the initial determination of the validity of a broker's proxy is made by the inspectors of election, whose decision is subject to judicial review. ${ }^{22}$

Function and Power of Inspectors of Election. Although inspectors of elec-

${ }^{21}$ Rule X-14A-3(b), 17 Code Fed. Reg. 240.14-A-3(b) (Cum. Supp., 1956).

${ }^{23}$ Consult p. 659 infra. 
tion are employed in almost every election or vote where the corporation is of substantial size, the use of inspectors is not mandatory in the absence of a statutory or by-law requirement. However, most corporations will provide for the use of inspectors in a by-law provision, regardless of the presence or absence of statutory requirements.

The inspectors of election do not conduct the corporate meeting. That is the function of the presiding officer. The chief duty of the inspectors is to count the votes, and their other duties are incidental to that function. These incidental duties are made necessary by the proxy system of voting. To determine the validity of a ballot cast by a proxy agent, it is necessary for the inspectors to ascertain whether or not the agents in fact have proxies for the number of shares they seek to vote by their ballot, whether or not the proxies were executed by stockholders entitled to vote, and whether or not the proxies executed were valid.

The extent of the inspectors' powers to determine the validity of a proxy is often a difficult problem. There is very little decisional law on this subject, and many of the answers must be determined by the practicalities of the situation.

The courts have been emphatic in stating that the inspectors of elections are ministerial rather that judicial officers. ${ }^{23}$ As a general rule, the inspectors of election must accept a proxy which is apparently genuine and valid on its face. ${ }^{24}$ It has even been stated that the inspectors have no power to determine any disputed questions. ${ }^{25}$ On the other hand, it has been stated that inspectors may exercise discretionary powers, particularly where irregularities appear on the face of a proxy. ${ }^{26}$

Little insight into the real problem can be gained from the general rules and descriptive language, such as "ministerial" or "prima facie validity." The particular situations which may confront the inspector, during his examination of brokers' proxies, should be considered separately.

Effect of the Stock Exchange Rules. Where a broker is a member of an exchange, the exchange regulations will restrict his right to vote or to give a proxy for stock now owned beneficially. However, when a broker's proxy is

${ }^{23}$ Matter of Lake Placid Co., 274 App. Div. 205, 81 N.Y.S. 2d 36 (3d Dep't, 1948), appeal denied, 298 N.Y. 932 (1949); Matter of Cecil, 36 How. Pr. (N.Y.) 477 (1869); Standard Power \& Light Corp. v. Investment Associates, Inc., 29 Del. Ch. 593, 51 A. 2d 572 (1947); Atterbury v. Consolidated Coppermines Corp., 26 Del. Ch. 1, 20 A. 2d 743 (1941); Bache v. Central Leather Co., 78 N.J. Eq. 484, 81 Atl. 571 (1911); Gow v. Consolidated Coppermines Corp., 19 Del. Ch. 172, 165 Atl. 136 (1933).

s Matter of Cecil, 36 How. Pr. (N.Y.) 477 (1869) ; Gow v. Consolidated Coppermines Corp., 19 Del. Ch. 172, 165 Atl. 136 (1933); In the Matter of Election of St. Lawrence Steamboat Co., 44 N.J.L. 529 (1882) ; Thompson v. Blaisdell, 93 N.J.L. 31, 107 Atl. 405 (1919); Gentry Futch Co. v. Gentry, 90 Fla. 595, 106 So. 473 (1925).

2 Prigerson v. White Cap Sea Foods, Inc., 100 N.Y.S.2d 881 (Sup. Ct., 1950).

${ }^{28}$ Matter of Burke v. Wiswall, 193 Misc. 14, 85 N.Y.S.2d 187 (Sup. Ct., 1948). 
presented to the inspectors of election, that proxy has the same quality of prima facie validity as any other proxy. Moreover, the proxy is not rendered invalid by the absence of a showing that the directions in the proxy do, in fact, represent the instructions received from the broker's customer. ${ }^{27}$ The law is summarized in the following quotation from a federal court case:

An equitable owner of shares who permits them to stand in his broker's name impliedly authorizes the broker to vote them. ... The broker, as registered owner, is entitled to vote the stock registered in his name. ... The fact that brokers may be obliged, under the rules of the New York Stock Exchange or under any other requirement of law or regulation, to obtain the consent of their customers before voting stock does not alter the rule of law in this respect; the presumption being that in the absence of proof to the contrary . . . consent had been obtained. ${ }^{28}$

This principle leads to the following practical conclusions. If the validity of a proxy executed by a broker (who is an exchange member) is challenged on the ground that the broker had not received instructions on how to vote the stock from its beneficial owner, the inspectors of election should reject the challenge and accept the proxy. The proxy has been executed by the registered owner of the stock. As such owner, the broker had the right to vote. It is no concern of the inspectors that the action of the brokers may have been in violation of a rule of the securities exchange of which he is a member. If the validity of a broker's proxy is challenged on the ground that the proxy does not represent or is in contradiction to the instruction that the broker had received from his customer, the same result must follow.

A remedy which may be available to challenge the accuracy of a broker's proxy prior to or during the meeting is an appeal to the officers of the stock exchange of which the broker is a member. If the exchange can be convinced that the broker has voted shares without receiving authorizations or has voted contrary to the authorizations received, the exchange may require the broker to execute a new and accurate proxy.

Ambiguities in Vote Tabulation. Inspectors are confronted with troublesome problems relating to brokers' proxies when a broker's proxy is overvoted (i.e. the aggregate number of shares represented by his one or more proxies is greater than the number of shares registered in his name) or when a broker executes proxies to both sides in the contest, which may not constitute an over-voting, but which render ambiguous the tabulation of the votes

${ }^{\pi}$ In re Pressed Steel Car Co., 16 F. Supp. 329 (W.D. Pa., 1936); Accord: In re Baldwin Locomotive Works, 21 F. Supp. 94, 99 (E.D. Pa., 1937); McLain v. Lanova Corp., 28 Del. Ch. 176, 39 A. 2d 209 (1944). Consult also, Matter of D. J. Salvator, Inc., 268 App. Div. 919, 51 N.Y.S. 2d 342 (2d Dep't, 1944). "[F] ailure to have shares registered so as to indicate an interest in others than the registered holder may reasonably be deemed a manifestation of intent that the corporation should deal freely with the registered holder as the true owner without investigating his authority." In re Northeastern Water Co., 28 Del. Ch. 139, 151, 38 A. 2d 918, 924 (1944).

${ }^{2}$ In re Pressed Steel Car Co., 16 F. Supp. 329, 336 (W.D. Pa., 1936). 
because of possible revocations. These problems occur because of the manner in which brokers execute their proxies.

As we have seen, the broker may not vote stock held in street name, upon a contested matter, without the instructions of the beneficial owner. As instruction cards are received by the broker, he has two alternatives with respect to executing proxies. He can keep a running tabulation of the instructions; and, on the day of the meeting, he can execute the proxies to the different factions which represent the net aggregates of the instructions received. Or, he can periodically tabulate the instructions, and execute proxies that represent his customers' instructions up to that particular moment. It is the latter practice which causes much of the difficulty.

The nature of these difficulties can best be illustrated by using hypothetical examples. Let us assume that Broker " $\mathrm{A}$ " is the registered owner of 1,000 shares of stock. These shares are beneficially owned by 1,000 customers of Broker " $A$," each owning one share. Broker " $\mathrm{A}$ " receives solicitation material and instruction cards from two soliciting groups, Management and Committee, which he transmits to his customers. On the basis of the instructions received, he executes proxies to the soliciting groups. At the election management holds a proxy from Broker "A" for 600 shares; Committee holds a later one for 500 shares. In the first place, Broker " $\mathrm{A}$ " has overvoted, because he is the registered owner of only 1,000 shares. Viewing this as the problem, what should the inspectors do? They could deduct 50 votes from each proxy; but there would be no reasonable basis for doing that; nor would there be any more reasonable basis for deducting the entire over-vote from Management because Committee has the later proxy. When possible revocations are considered, the problems multiply. On the ground that a later proxy from a stockholder revokes an earlier one, even though the form of proxy may not so state, it can be said that Broker "A's" proxy to Committee is a complete revocation of the earlier proxy to Management, and that the inspectors should count 500 votes for Committee and none for Management. This could be countered by the suggestion that since Broker " $\mathrm{A}$ " is registered for 1,000 shares and since Committee is admittedly entitled to 500 votes, it is possible that the other 500 shares represented by the first proxy are held for different customers of Broker "A." On this theory, the vote should be split, 500 to Management and 500 to Committee.

The revocation problem can exist without the possibility of an over-voting. Assume Broker "B" (registered owner of 1,000 shares) executes a proxy to $\mathrm{X}$ for 500 shares, and a later proxy to $Y$ for 300 shares. The possibilities are: (1) that the later proxy is a complete revocation of the earlier one, so that $Y$ is credited with 300 shares and $\mathrm{X}$ with none; (2) that all of the 300 shares covered by Y's proxy represent customer accounts different from any of the 500 shares covered by $X$ 's proxy, so 500 shares are credited to $X$ and 300 to 
$\mathrm{Y}$; (3) that all of the 300 represent the same customers, so the shares are credited 200 to $\mathrm{X}$ and 300 to $\mathrm{X}$; or (4) any allocation among these various extremes. The fact is that, with nothing more to go by than what appears on the face of the proxies, there is no way for the inspectors to make a logical allocation of the votes between the two factions. This results from the fact that the form of the proxy does not indicate which of the customer accounts are represented. ${ }^{29}$

Resolving Ambiguities by Inspectors. There are two cases which furnish some guide to the proper action by the inspectors in these situations. In Wilson v. Rensselaer \& Saratoga R.R. Co., ${ }^{30}$ a broker executed one proxy covering 1,810 shares to be voted for a proposed merger, and a later proxy covering 40 shares to be voted against the merger. It was contended that the later proxy, which was a printed one carrying the legend that it reroked all prior proxies, constituted a revocation of the entire 1,810 shares covered by the earlier proxy. This contention was rejected by the court on two grounds; first, because it was clear that the shares in each proxy represented different customer accounts; and second, because the revocation clause in the second proxy was overcome by a restriction stamped on the proxy by the broker, which read:

This proxy does not revoke any proxy previously given by the undersigned to vote at said meeting. This proxy shall not be deemed to be revoked by any proxy subsequently given by the undersigned which refers to less than all the shares which the undersigned shall be entitled to vote at such meeting. ${ }^{31}$

The stamped restriction affixed by the broker can make possible, in most cases, an effective determination of the allocation of votes. For example, if a broker is the registered holder of 1,000 shares and executes one proxy for 600 shares to one faction and a later one for 300 shares to the opposing faction, the stamped restriction, offsetting the ordinary rules of revocability makes it clear that the vote is to be allocated 600-300. However, what if the broker executes a proxy for 700 shares to one side and a later proxy for 400 shares to the other side? Since the later proxy is for less than all the shares which the broker is entitled to vote, the stamped restriction operates to negate any revocation. Yet the total number of shares voted is greater than the number of shares registered in the broker's name, so that some of the customers represented by the first proxy may have changed their minds and given new instructions to the broker. Unless there is something on the face of the proxy

These examples are based, in part, on actual cases discussed in McGoldrick v. Rotwein, 127 N.Y.L.J. 508, col. 7 (Sup. Ct., Feb. 6, 1952), CCH N.Y. Corp. Law Rep. I 10,546.

${ }^{30} 184$ Misc. 218, 52 N.Y.S. 2d 847 (Sup. Ct., 1945), aff'd 268 App. Div. 1076, 53 N.Y.S. 2d 306 (3d Dep't, 1945).

31 Ibid., at 222, 850 . 
to indicate how many shares were involved in the switching, there is no way for the inspectors to make a reasonable allocation of the 1,000 shares registered in the broker's name. Thus, where the broker's shares are over-voted, a not uncommon occurrence, the stamped restriction negating revocation does not solve the problem.

The second case which dealt with brokers' proxies is McGoldrick v. Rotwein, ${ }^{32}$ a case which indicates how carelessly executed brokers' proxies can make a shamble of a corporate election. Although the court was asked to determine how the votes of over fifteen brokers should have been counted, the court was able to make a determination in only two situations. In the first, a broker who held 4,000 shares issued a proxy to one side for 4,000 shares, and a later proxy to the other side for 4,000 shares. The inspectors divided the vote, giving 2,000 shares to each side. This the court held to be error since the later proxy was a complete revocation of the earlier proxy.

In the second situation, a broker who held 600 shares gave a proxy for 700 shares to one side, and a later proxy to the other side which did not specify a number of shares. The inspectors credited 300 shares to each side. The court held that 600 shares should have been credited to the holder of the later proxy, for although it did not specify a number of shares, it must be deemed to have been for all the shares owned of record and was a complete revocation of the earlier proxy. The court added that since the earlier proxy was addressed to all of the firm's shares of record (actually, 100 more than it held), it left no room for any theory of division of shares.

In the other situations, similar to the hypothetical examples given above, the court was unable to make any determination whatsoever, ${ }^{33}$ for, as the court stated:

In no case would examination of the proxy itself reveal any allocation of the shares it purported to vote among the brokerage firm's customers-the beneficial owners. The component stock units which presumably aggregated the total number of shares represented by the proxy were in no instance particularized or otherwise distinguished by the name of customer, account number, code number, or even by setting forth the number of shares constituting each customer's stock interest. As a consequence of the inability to ascertain which beneficial owner's shares were represented by any particular proxy, it is impossible in many instances to determine whether later proxies for less than the entire number of shares standing in the name of the brokerage firm revoked earlier proxies issued by the same firm. ${ }^{34}$

${ }^{32} 127$ N.Y.L.J. 508, col. 7 (Sup. Ct., Feb. 6, 1952), CCH N. Y. Corp. Law Rep. ๆ 10,546.

${ }^{33}$ For example: "In the case of Carreau \& Company, a proxy for 500 shares was issued to Markey on September 7, and a proxy for 500 shares to petitioners on October 2. The firm was record owner of 600 shares. It is possible that 100 of the 500 shares involved in the proxy to Markey were not included in the later proxy to petitioners. It is therefore impossible to determine whether the earlier proxy to Markey should be regarded as entirely revoked or revoked only as to 400 of the 500 shares." Ibid.

st Tbid. 
This inability to identify the shareholdings represented by the various proxies caused the court to determine that the peremptory relief asked for in the case was inappropriate. A trial would be necessary where affirmative evidence could be offered with the opportunity to cross-examine.

The McGoldrick case is important for the bearing it has on the crucial question of the authority of the inspectors to look at external evidence to determine the real intent of over-voted or ambiguous brokers' proxies. The court noted that one faction in the contest had tendered to the inspectors of election affidavits which had been obtained from various brokerage firms after the date of the election. These affidavits requested the inspectors to tally their clients' shares in the manner stated. The inspectors refused to consider these affidavits on the ground that they could not receive extrinsic evidence but were required to determine the manner in which the proxies were to be tallied from the proxies themselves.

The court did not expressly state that the position taken by the inspectors was the proper one, but such a view can be implied from its conclusion that a trial was necessary to take proof on the identity of the shareholdings represented by the various proxies. The court directed that, at such a trial, none of the parties should be concluded by the brokers' affidavits that had been secured by the one faction, because it was conceivable that the other factions, had they attempted to solicit affidavits of a similar type from the same and other brokers, might have obtained affidavits favorable to them.

In the 1954 contest for control of the New York Central Railroad, this same problem of over-voted brokers' proxies confronted the inspectors of election. ${ }^{35}$ The management side contended that, as purely ministerial officers, the inspectors could take no action other than to reject the proxies. ${ }^{36}$ The insurgent side argued that the inspectors (who were three law school professors) should depart from their purely ministerial function and look to extrinsic evidence in the form of affidavits from the brokers explaining their actual intent. The inspectors adopted the insurgents' position and tabulated the over-voted broker vote on the basis of brokers' affidavits. One of the reasons that motivated them to do this was the belief that it was their duty to do everything reasonably within their power to prevent a stockholder from being disenfranchised.

By reason of the practicalities involved, it appears that the position taken

${ }^{35}$ The information on the New York Central contest is taken from an address by $\mathrm{Mr}$. Russell T. Walker delivered before the Practising Law Institute on August 2, 1954. The text of the address is available in mimeographed form from the American Society of Corporate Secretaries, Inc., 10 Rockefeller Plaza, N.Y.C.

${ }^{36}$ Although not the reason for their argument, it may be noted that in the final count the broker-held stock was voted 1,070,000 for the insurgent Young group and 652,000 for the management. 
by the New York Central inspectors was the correct one and should be adopted in future cases. The over-voting which appears in brokers' proxies is due to clerical errors by the brokers' proxy departments in tabulating the instruction cards received from customers. Very often a customer will change his mind during the course of the proxy campaign, and as a result the broker will receive a number of conflicting instructions from his customers. Only the last instruction received should be represented in the proxies that the broker executed to the various contesting groups: but through clerical errors in cancelling earlier instruction cards from the same customers, the same shares may be represented in more than one proxy.

Whatever the cause of the over-vote, or whatever the ambiguity due to possible revocations in later executed proxies, the true intent of the broker's customers can be determined by a retabulation and check for duplicates in the customers' instruction cards. There is no valid reason why the broker should not be allowed to make such a re-examination of his instructions, and express the result in an affidavit which will enable the inspectors of election to count the broker's proxy in a way that will accurately represent the intent of the beneficial owners of the shares. Should the situation arise which was contemplated by the court in the McGoldrick case, viz., that the opposing sides produce conflicting affidavits from the same broker, then the inspectors should reject the proxy in toto because that presents a situation requiring judicial determination.

Methods of Preventing Ambiguities. The difficulties in "lifting the proxy veil"37 which may require the inspectors to look to extrinsic evidence could be avoided if the brokers employed a form of proxy that contained a breakdown of the total number of shares being voted by the proxy into the several shareholdings of the customers who have instructed the broker to vote in that particular way. This breakdown could appear either on the face of the proxy or in a separate document physically attached to the proxy. Since brokers avoid revealing the identity of their customers, some other form of identification could be used. A simplified example will illustrate how such identification of holdings could guide the inspectors.

Assume that a broker is the registered holder of 16 shares. He executes one proxy to the management for 10 shares. This proxy carries the legend that the 10 shares represent 6 shares held in "Account A," 2 in "Account B" and 2 in "Account C." The same broker executes a later-dated proxy to the insurgents for 8 shares, which proxy carries the legend that the proxy represent 6 shares in "Account D" and 2 shares in "Account B." Since the aggregate of shares voted is 18 , the broker apparently has over-voted. How-

\footnotetext{
${ }^{97}$ McGoldrick v. Rotwein, 127 N.Y.L.J. 508, col. 7 (Sup. Ct., Feb. 6, 1952), CCH N.Y. Corp. Law Rep. I 10,546.
} 
ever, by examining the information appearing on the face of the proxy (or attached papers), the inspectors can see that the 2 shares held in the broker's "Account B" are represented in both proxies; and since the proxy to the insurgents was later in date, the inspectors know they are accurately interpreting the customers' intent by counting 8 shares for the management (although the proxy says 10 shares) and 8 shares for the insurgents.

This method of identifying shareholdings on the face of the proxy is subject to the criticism that, in the case of a broker holding many shares of stock in a particular company for a large number of customers, the computation and presentation of individual shareholdings imposes a great burden on the broker and an even greater burden and time-consuming chore on the inspectors who will have to make comparisons between the various computations to cancel duplicates.

It probably would be easier on both the broker and the inspectors to wait until the proxies are presented, to see if any over-voting or ambiguities appear; and then if they do, the broker can re-check his own instruction cards and present the result to the inspectors in summary fashion by affidavit.

It is manifest from the above discussion that most problems concerning brokers' proxies can be avoided by the brokers' exercising care in cancelling duplicate instruction cards and executing proxies which contain clear directions as to whether a later proxy is intended to revoke an earlier one, and if it is, as to how many shares represented by the earlier proxy are intended to be revoked. For example, assume a broker is the registered holder of 1,000 shares. He gives a proxy for 400 shares to one side and a later proxy for 400 shares to another side, the latter proxy stating that it is intended to revole 200 shares represented by the earlier proxy. The inspectors then know that they should count 200 shares for the holder of the first proxy and 400 shares for the holder of the second one.

It may well be that some of the more troublesome problems presented by the brokers' proxies would be eliminated if the stock exchanges adopted a rule which prescribed one or more forms of proxy to be used by brokers. These should be designed to eliminate or minimize the possibilities of overvote or undefined revocations. Such a rule could require a final proxy which would clearly and definitively give the cumulative or net vote for each side and on each proposition.

Needless to say, a soliciting group should exercise great care in dealing with brokers' proxies and should be prepared to clarify ambiguities before the meeting gets under way. As a practical matter, the professional proxy solicitor is probably best able to check the final tabulations with the proxy clerks of brokerage firms in order to avoid errors of over-voting or revocations. This should be done before the brokers actually deliver their final proxies. 


\section{Determination BY THE COURTS}

In addition to the rather limited consideration by the inspectors of election, questions concerning stockholders' proxies, including brokers' proxies, are subject to judicial review and determination. Such review may occur before, during or after the stockholders' meeting. Since the courts exercise judicial power, as distinguished from the supposedly "ministerial" power exercised by the inspectors of election, the courts usually may grant broader and more effective relief. However, the courts, in certain situations, are restricted by special statutes or doctrines. ${ }^{38}$

Judicial Remedies Prior to or During the Meeting. Questions or disputes concerning proxies may arise before the meeting. They may even arise during a meeting; especially if it is in extended recess. A conflict may develop as to who, if anyone, has the right to vote or give a proxy for certain stock. While, as far as the corporation is concerned, the record stockholder may be the only one entitled to vote, the beneficial owner usually has the right to direct how his stock should be voted. ${ }^{39}$ The beneficial owner may attempt to enforce his rights by bringing a proceeding either to obtain a proxy from the record owner ${ }^{40}$ or to enjoin the record owner from voting. ${ }^{41}$

However, if the record holder is a broker who is a member of a national exchange, it is doubtful that the beneficial owner will find it necessary or expedient to resort to legal remedies. If the broker wrongfully refuses to give a proxy or vote as directed, a complaint to the officials of the particular securities exchange would probably bring quick relief. ${ }^{42}$ On the other hand, if there is a bona fide dispute between the broker and the alleged beneficial owner, the institution of legal proceedings may be required.

Post-Meeting Review. Questions concerning the validity or recognition of proxies, including brokers' proxies, may be raised in judicial proceedings after

${ }^{38}$ Consult Aranow \& Einhorn, State Court Review of Corporate Elections, 56 Col. I. Rev. 155 (1956).

${ }^{3}$ Commissioner of Int. Rev. v. Southern Bell Tel. \& Tel., 102 F. 2d 397 (C.A. 6th, 1939); In re Canal Const. Co., 21 Del. Ch. 155, 182 Atl. 545 (1936); Wilson v. Rensselaer \& Saratoga R.R. Co., 184 Misc. 218, 52 N.Y.S. 2d 847 (Sup. Ct., 1945), aff'd 268 App. Div. 1076, 53 N.Y.S. 2d 306 (3d Dep't, 1945).

${ }^{40}$ In re Giant Portland Cement Co., 26 Del. Ch. 32, 21 A. 2d 697 (1941); Thompson v. Blaisdell, 93 N.J.L. 31, 107 Atl. 405 (1919); Section 47, New York Stock Corporation Law, specifically empowers the beneficial owner to obtain a proxy from the record owner. Consult, In re Atlantic City Ambassador Hotel Corp., 62 N.Y.S. 2d 62 (Sup. Ct., 1946).

"In re Canal Const. Co., 21 Del. Ch. 155, 182 Atl. 545 (1936); American National Bank v. Oriental Mills, 17 R.I. 551, 23 Atl. 795 (1891). See also, Vowell v. Thompson, 3 Cranch C.C. 428 , Fed. Case No. 17,023 (1829); 5 Fletcher Cyclopedia Corporations $\$ 2072$ (rev. ed., 1952).

12 Rule 872 of the New York Stock Exchange Rules requires a member to vote as directed by the beneficial owner. Although a court will not enforce these private rules, the Exchange can effectively enforce them through its self-disciplining powers. 
the stockholders' meeting. Twelve states have passed specific statutes providing for judicial review of corporate elections. ${ }^{43}$ In those states which do not provide a special review proceeding, a corporate election is subject to judicial review through "quo warranto" proceedings. ${ }^{44}$

The courts, in the course of such judicial review, generally may look beyond the face of a proxy and receive extrinsic evidence bearing on the questions involved. They are, therefore, somewhat better able to determine problems arising from over-voting or revocations which are so often associated with brokers' proxies. In endeavoring to ascertain the intent of the broker, as well as the surrounding facts and circumstances, the court may accept and consider affidavits from the broker or it may conduct a hearing with the presentation of formal proof and the right of cross-examination.

The latter course was adopted by the court in McGoldrick v. Rotwein ${ }^{45}$ when a correct tally could not be established from the face of the proxies alone. Affidavits from the brokers had been offered by one side but rejected by the inspectors of election. The court also refused to determine the issues on the basis of the affidavits of only one side and decided that a trial was necessary. The court reasoned that the other side might have been able to obtain additional or contrary affidavits if it had attempted to do so, and that at a trial each side would have the opportunity to cross-examine and to present affirmative evidence. It would seem, however, that in most cases involving brokers' proxies, the basic issues and facts should be rather narrow and susceptible of proof by affidavits in a summary proceeding, and that a trial should be held only (1) where the affidavits of both sides conflict, or (2) where all the brokers whose proxies are disputed have not submitted affidavits, and the votes thus represented would be sufficient to affect the outcome of the contest.

Different problems are presented when it is claimed that a broker's proxy was not executed in accordance with the instructions of the beneficial owner. There are various possibilities: (1) Where instructions of the beneficial owners are required by the rules of the stock exchange (because the matter to be voted on is being contested or substantially affects a legal right) and (a) the broker executed a proxy without receiving such instructions or (b) executed a proxy contrary to such instructions or (c) executed no proxy even though he received such instructions; (2) Where no instructions of the beneficial owner are required and (a) the broker executed a proxy contrary to the instructions given him by the beneficial owner and (b) the broker executed no proxy even though he had received such instructions.

${ }^{23}$ Aranow \& Einhorn, State Court Review of Corporate Elections, 56 Col. L. Rev. 155 (1956).

"Ibid.

${ }^{2} 127$ N.Y.L.J. 508, col. 7 (Sup. Ct., Feb. 6, 1952), CCH N.Y. Corp. Law Rep. ๆ 10,546. 
There is little authority on these questions. Since the beneficial owner usually has the right to direct how his stock should be voted, it would seem that, where the broker has disregarded the instructions of the beneficial owner, the court should void and, if possible, deem a proxy to have been executed in accordance with the instructions of the beneficial owner. ${ }^{46}$ Likewise, if the broker failed to give a proxy when instructed to do so by the beneficial owner, it would seem that the court should declare that such proxy had been given. Where the beneficial owner gave no instructions with respect to a matter which, according to the rules of the stock exchange, required specific instructions, and where the broker nevertheless gave a proxy, it would seem that the proxy is valid and should be so recognized by the court.47

Determination of the above problems in a judicial proceeding brought after the stockholders' meeting is often further complicated by the limited power or authority of the court itself. The remedies which the court may grant may be limited. ${ }^{48}$ In some states, by reason of statute or decision, the corporate stock books may be deemed conclusive, even on the courts. There may be restrictions on who can institute the proceeding and raise the questions for judicial determination and there may be the further rule that judicial review will be granted only if corrections of the alleged error will change the ultimate result. 40

Thus, before undertaking a post-meeting judicial review of the validity of brokers' proxies, it is necessary to consider the yariety of applicable statutes and decisions affecting the powers of the court and the circumstances under which it will exercise those powers. Consideration of these matters is beyond the scope of this article. ${ }^{50}$

\footnotetext{
${ }^{16}$ In re Canal Const. Co., 21 Del. Ch. 155, 182 Atl. 545 (1936); in this case, after first determining that the beneficial owner could have enjoined the voting of his stock contrary to his wishes, the court reasoned: "If, then, the complainant (the record holder) would be prevented from voting the stock in suits by the owners directly challenging his right to do so, it follows in this review proceeding that the court ought not to recognize his right to vote. ..." Ibid., at 162, 548. See also, In re Pressed Steel Car Co., 16 F. Supp. 329 (W.D. Pa., 1936) ; In re Baldwin Locomotive Works, 21 F. Supp. 94 (E.D. Pa., 1937); In re Giant Portland Cement, 26 Del. Ch. 32, 21 Atl. 697 (1941).
}

${ }^{17}$ See In re Pressed Steel Car Co., 16 F. Supp. 329 (W.D. Pa., 1936); In re Baldwin Locomotive Works, 21 F. Supp. 94 (E.D. Pa., 1937); McLain v. Lanova Corp., 28 Del. Ch. 176, 39 A. 2d 209 (1944). "[B]ut, even in this proceeding it can hardly be contended that the actual consent of the holder of the certificate is ordinarily essential to the right of the record owners to vote stock outstanding in their names." In re Giant Portland Cement, 26 Del. Ch. 32, 41, 21 A. 2d 697, 702 (1941).

${ }^{23}$ In New York, the court, under section 25 of the General Corporation Law, may either confirm an election or order a new one. It cannot correct the result.

4 Consult Aranow \& Einhorn, State Court Review of Corporate Elections, 56 Col. L. Rev. 155 (1956), for a discussion of the New York and Delaware Statutes.

${ }^{\text {so }}$ Ibid. 